\title{
OCHRANA ZÁJMŮ SPOTŘEBITELŮ JAKO SOUČÁST KONCEPCE SPOLEČENSKÉHO MARKETINGU?
}

\author{
Pavla Sýkorová, Halina Starzyczná, Emanuel Šustek
}

\section{Klíčová slova:}

koncepce společenského marketingu, etika v podnikání, CSR, spotřebitelská politika EU, spotřebitelská politika ČR

\section{Key words:}

concept of social marketing, business ethics, CSR - Corporate Social Responsibility, EU consumer policy, consumer policy of Czech Republic

\begin{abstract}
Abstrakt:
Článek se zamýšlí nad problematikou vztahu společenského marketingu a ochranou zájmů spotřebitelů. Pokládá si otázku, jak může ochrana zájmů spotřebitelů přispět ke zkvalitnění uspokojování jejich potřeb. Vychází z teoretických poznatků této nejmodernější koncepce marketingu, základních dokumentů týkajících se ochrany jak v EU, tak v ČR a v návaznosti na to prezentuje nejznámější př́ílady z praxe jak v tom pozitivním, tak negativním slova smyslu na vybraných prvcích marketingového mixu.
\end{abstract}

\begin{abstract}
:
The article speculates about the problems of relations of the social marketing and protection of interests of consumers. It relates from theoretical knowledges of this most modern marketing conception, from basic documents, which are concerned in the protection in the EU and in the Czech Republic. The paper presents the most known positive and negative schedules according to select components of marketing mix.
\end{abstract}

\section{Úvod}

Marketing je o zákaznících, píše P. Kotler v jedné ze svých knih. [3, s. 37] Dnešní úspěšné společnosti na trhu se výrazně orientují na zákazníka a jsou silně marketingově zaměřené. Nejedná se pouze o velké společnosti, ale i menší firmy, které si postupně budují vztahy se svými zákazníky. Zpočátku byl marketing chápán jako snaha přesvědčit a prodat, v současnosti ale stále více nabývá nového významu, a to nejen prodat, ale i uspokojit zákazníkovu potřebu. K míře uspokojení zákazníka dle našeho názoru může přispět i akceptování ochrany zájmů spotřebitelů a dodržování veškeré legislativy s tím spojené.

Tradiční marketing, resp. transakční marketing [21, s. 148-156] se postupně změnil v marketing vztahový, který se orientuje na dlouhodobé výsledky. Tyto vztahy lze budovat kvalitními produkty, dobrými službami a optimálními cenami. Hlavním cílem obchodních společností byla maximalizace zisku z každé jednotlivé transakce. Ukazuje se, že dlouhodobý vztah můžeme vybudovat pouze tehdy, jestliže budujeme vzájemně prospěšné vztahy se svými zákazníky. V silném konkurenčním prostředí na současném globalizovaném trhu není jednoduché si vytvářet sítě svých loajálních zákazníků. Zejména v období hospodářské krize jsou zákazníci citlivější na ceny, nebot' jejich př́ijmy se ztenčují. Přesto dochází k budování poměrně propracovaných systémů péče o zákazníky, což je důsledek právě již zmiňovaných 
konkurenčních tlaků, které jsou vedle internacionalizace a koncentrace jedním z charakteristických trendů globalizace.

Zabezpečení potřeb zákazníků se nedá aplikovat, aniž bychom se snažili uspokojit jejich potřeby lépe než konkurence, a to tak, aby byl zachován nebo zvýšen užitek zákazníka i celé společnosti. Toto je motto nejmladší z marketingových filosofií tzv. „koncepce společenského marketingu“, resp. společensko-etického marketingu. Tato koncepce dle našeho názoru musí být brána $\mathrm{v}$ úvahu při budování vztahů se zákazníky. V praktické rovině by součástí vztahového marketingu měla být i péče o zákazníka a jeho ochrana. Pokud společnost nemá dostatečné povědomí o etických aspektech prodeje, musí přijít na řadu stát, který vytváří $\mathrm{k}$ ochraně spotřebitelů potřebnou legislativu v rámci koncepce spotřebitelské politiky, která je součástí hospodářské politiky země či integrace, jejíž součástí tato země je.

Cílem prezentovaného článku je hodnocení vztahů mezi koncepcí společenského marketingu a ochranou zájmů spotřebitelů. Článek se opírá o vybrané teoretické zdroje zabývající se problematikou marketingové etiky a sekundární výzkum zaměřený na praktické projevy ochrany spotřebitelů v rámci EU a ČR. Prezentované poznatky jsou dílčí částí zamýšleného primárního výzkumu zaměřeného na problematiku ochrany zájmů spotřebitelů v ČR a ověření aplikace společenského marketingu v praxi. Problematika spojení ochrany zájmů spotřebitelů s koncepcí společenského marketingu může vyvolat různé názory, i negativní. Náš článek má záměr upozornit na tuto možnost propojení, protože se domníváme, že úroveň uspokojení potřeb zákazníků by měla být v souladu s ochranou zájmů spotřebitelů a tedy i celé společnosti.

\section{Koncepce společenského marketingu (sociálně etického) v teorii}

Pojmologie v oblasti etiky podnikání není zcela ujasněná. Nejčastěji se setkáváme s pojmem podnikatelská etika [2, s. 16] $]^{1}$, společenská odpovědnost firem (CSR - (Corporate Social Responsibility) a z hlediska marketingu společenský marketing.

Koncepce společenského marketingu je v odborné literatuře definována relativně jednotně. Definice se liší pouze $\mathrm{v}$ konkrétní formulaci. Vrat'me se $\mathrm{k}$ definici společenského marketingu podle Kotlera, jak jsme se již zmínili v úvodu našeho článku. Vychází z předpokladu, že by firma měla zjistit potřeby, přání a zájmy cílových trhů a zajistit požadované uspokojení lépe a účinněji než konkurence takovým způsobem, aby byl zachován nebo zvýšen užitek zákazníka a celé společnosti. [3, s. 53] Koncepce společenského marketingu má 3 pilíre (viz obrázek 1.1), o které se opírá: spotřebitele a uspokojování jeho potřeb, zisky firem a společnost a její blahobyt. Vytváření marketingové politiky by mělo všechny tři pilíre uvádět do rovnováhy. Společnost očekává od firem, že budou dodržovat základní etické a ekologické normy.

\footnotetext{
${ }^{1}$ Pojem etika se odvozuje od starořeckého slova étos, což znamená mrav, zvyk, obyčej nebo charakter, jak uvádí autor B. Fiala.
} 


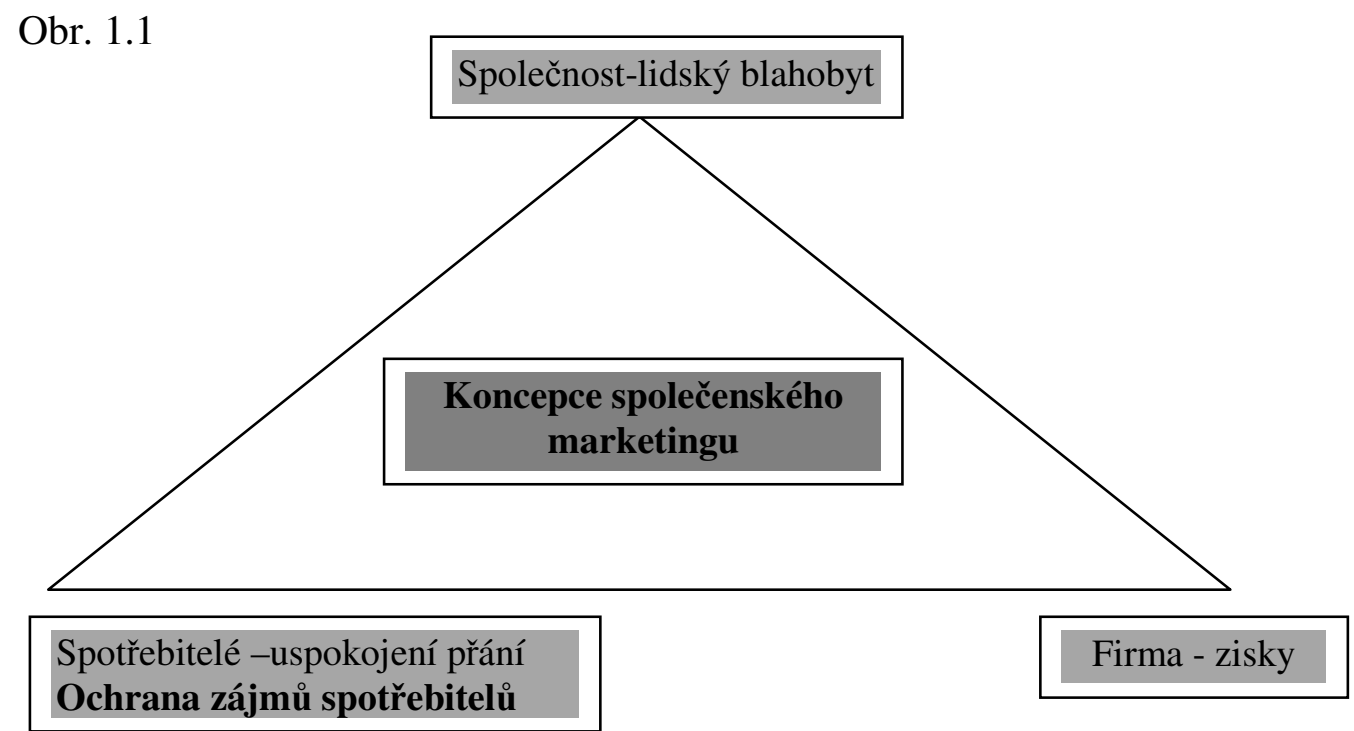

Pramen: Vlastní úprava dle KOTLER, P., WONG, V., SAUNDERS, J., ARMSTRONG, G. Moderní marketing. Praha: Grada Publishing, 2007. s. 285. ISBN 978- 80-247- 1545-2.

Obdobným způsobem hovoří M. Zamazalová o sociálně-etickém marketingu [7, s. 36], který vyhledává soulad mezi potřebami a přáním zákazníků, zájmem firmy a sociálními, etickými a dalšími zájmy společnosti (např́klad ekologie). Všechny aktivity společnosti by měly $\mathrm{v}$ rámci společenského marketingu směřovat $\mathrm{k}$ tomu, aby byla zajištěna spokojenost zákazníka. „Neetický marketing znamená porušení etiky, užívání neetických praktik v marketingu k dosažení firemních cílů anebo dokonce individuálních cílů manažera“. [14, s. 254]

Koncepci společenského marketingu vytvářejí zaměstnanci podniku, kteří se liší svými př́stupy k etickému vnímání vztahů se zákazníky. Koncepce ovlivňuje celý proces strategického marketingového plánování. Lidé ovlivňují podnikatelské prostředí a jeho rozvoj. Nejsou to jenom vnější vlivy, které působí na chování podniku, ale i interní. Tvorbu etiky v podnikatelském prostředí podle Dytrta ovlivňuje řada faktorů, z nichž můžeme jmenovat např. partnerskou spolupráci všech podnikatelských organizací, veřejných a správních institucí, které mohou její úroveň ovlivňovat, dále sledování a ovlivňování vývoje neměřitelných vlastností podnikových jevů bezprostředně ovlivňující etický rozměr managementu, systematické zkoumání vztahů mezi kvalitativními a kvantitativními vlastnostmi ekonomických jevů a využívání získaných poznatků ve strategii řízeného objektu, kvalitu stimulace rozvíjení sociální odpovědnosti v managamentu apod. [1, s. 17]

Negativní př́íklady z praxe při neetickém jednání podniků, vedly i ke vzniku pojmu „Společenská odpovědnost organizací“, [1, s. 101] která dle našeho názoru souvisí se společenským marketingem, nebot' CSR by měla být zaměřena nejen dovnitř organizace, [6, s. 163$]^{2}$ ale i vůči okolí a celé společnosti. Spotřebitel je součástí marketingového mikroprostředí podniku a i když konkrétní aplikace CSR přímo nezdůrazňují spotřebitele jako takového, nepřímo se ho dotýká např. přes image podniku, přes výrobek, který je ekologický šetrný či jeho prodej je spojen s tzv. dobrou věcí apod. [4, s. 88] ${ }^{3}$

\footnotetext{
${ }^{2}$ I zde bychom našli podobnost s marketingovými aplikacemi. Viz Interní marketing, představující vztah $\mathrm{k}$ zaměstnancům organizace.

${ }^{3}$ Postoj spotřebitelů k CSR: Výzkum KPMG EKf VŠB-TU Ostrava v roce 2006.
} 
Vzrůstající zájem podnikatelů o etické audity, etické kodexy má různé př́iciny: tlak zahraničních obchodních partnerů, předpoklad zahraničních investic, změna postojů zákazníků, firemní kultura zahraničních mateřských společností, předpoklad stabilních obchodních vztahů, předpoklad kvalitních a stabilních zaměstnanců, snahy o kultivaci podnikatelského prostředí, ekonomické efekty, tlak nadnárodních institucí (EU, OSN) a státu, tlak společnosti apod. [4, s. 5-6]. Kvalitní uspokojování potřeb zákazníků by nemělo dle našeho názoru probíhat izolovaně bez ochrany zájmů spotřebitelů.

\section{Ochrana zájmů spotř̌ebitelů}

Problematika ochrany spotřebitelů má svůj historický vývoj. Jakmile se začal rozvíjet směnný obchod, začaly se objevovat první prvky ochrany spotřebitele, které souvisely se snahou upravit vztahy mezi prodávajícími a kupujícími. Mohli bychom tyto snahy hledat již ve středověku. [5, s. 14] Byly vydávány řády o trzích, o ochraně kupujících, pevné ceníky vybraných druhů zboží apod. Byl kontrolován obchod i řemesla. Garantem kvality byly cechy. Na novodobou úpravu tržního dozoru a ochrany spotřebitelů, která započala v 19. století, upozorňuje L. Matusiková ve své monografii. [5, s. 16] Čím více se rozvíjel trh po 2. světové válce, tím více rostla potřeba řešit situaci práv spotřebitelů.

Definovat pojem ochrany spotřebitele by bylo možné učinit mnohými způsoby, nebot' se jedná o velmi širokou oblast činností. Poměrně srozumitelnou formulaci použila O. Horová na konferenci k Novým teoriím ekonomiky a managementu organizací: jde o systematickou, cílevědomou činnost občanů a vlády státu, směřující k posílení postavení spotřebitele na trhu a k zajištění a udržování přiměřené ochrany mezinárodně uznaných práv spotřebitelů (především ochrana bezpečnosti a zdraví občanů). [10, s. 431] Podle Matusikové pak spotřebitelská práva jsou tvořena legislativním rámcem zákonů, nařízení, směrnic a pokynů, jež ve svém komplexním pojetí umožňují zajistit spotřebitelům ochranu v kontextu jejich působení na trhu zboží a služeb na úrovni předpokládané Koncepcí spotřebitelské politiky. [5, s. 12]

Souběžně s otázkami, které si pokládáme v souvislosti se společenským marketingem, hodnotíme legislativu, která vytváŕí podmínky pro podnikání. Nezabývá se jen ochranou podniků, ale dalším důvodem je právě ochrana spotřebitelů a ochrana zájmů celé společnosti. Důvodem pro určitou míru vládních regulací je ochrana spotřebitelů před různými nekalými praktikami obchodních podniků, které neváhají s prodejem nekvalitních výrobků, lžou zákazníkům při propagaci zboží a dopouštějí se různých nepoctivostí, které poškozují marketingovou koncepci jako takovou.

Vlády různých zemí se snaží definovat skutečnosti, které svědčí o nekalých a bezohledných obchodních aktivitách a vytvářejí legislativu, která se snaží bránit jejich používání. Prvním dokumentem, který měl celosvětovou působnost, byl dokument, který vydala OSN. Jednalo se o „Směrnici na ochranu spotřebitele“ (rezoluce Valného shromáždění OSN č. 39/248, 1985), [5, s. 19] která se stala jediným mezinárodně uznávaným sortimentem. ${ }^{4}$

Součástí veřejných politik i podnikových strategií se stávají v posledních letech také etické kodexy. Kromě kanadských a amerických etických kodexů, které se zaměřují hlavně na

\footnotetext{
${ }^{4}$ Směrnice obsahuje základní cíle a principy ochrany spotřebitelů. Současně působí jako nástroj podpory pro budování systému ochrany v jednotlivých zemích.
} 
vztahy zaměstnanců a firmy a problémy korupce a konfliktů zájmů, existují evropské etické kodexy, které svoji pozornost věnují především vztahům se zákazníky. [9, s. 219]

\section{Evropská unie}

Problematika ochrany spotřebitele $\mathrm{v}$ počátcích integrace chyběla. Základem spotřebitelské legislativy Společenství se stal „Předběžný program EHS o ochraně spotřebitele a informační politice“. Stalo se to v roce 1975. Evropská komise v něm predstavila pět základních práv spotřebitelů. Každý spotřebitel má podle něho právo na ochranu zdraví a bezpečnosti, ochranu ekonomických zájmů, náhradu škody, informace a vzdělávání a zastoupení. [27] Současně byl zdůrazněn průřezový charakter spotřebitelské politiky, což znamená, že bude postupně začleňována do zvláštních politik Společenství, jako je např. hospodářská politika, politika životního prostředí, energetická a dopravní politika apod. Po tomto úvodním dokumentu následovaly další. Zvláště je třeba vyzvednout Maastrichtskou smlouvu, která jako první zavedla ochranu spotřebitele jako samostatnou politiku. V článku. 129a (dnes čl. 153) položila nezbytný právní základ ochrany a pojala ji za plnohodnotnou komunitární politiku.

Trh EU se neustále rozšiřuje, vylepšuje i modernizuje. Občané EU mohou cestovat po celé EU díky vytvořenému trhu s volným pohybem osob, zboží služeb a kapitálu. Na trhu EU žije půl miliardy obyvatel (2010), [26] tedy potencionálních spotřebitelů, kteří mají svá práva chráněná právními předpisy EU. Povědomí o významu spotřebitelských zájmů, a to jak obecně, tak pokud jde o dopady oblasti ochrany spotřebitele na vnitřní trh, se stát od státu liší. Rovněž organizační aspekt ochrany spotřebitele je značně různorodý. To je dáno nejen tradicemi jednotlivých států či regionů nebo rozdíly mezi starými a novými členskými státy, ale i skutečností, že právní úprava je úpravou minimální. [27]

Základním principem politiky ochrany spotřebitele EU je zajistit spotřebitelům rovnoprávné postavení na vnitřním trhu. Spotřebitel by měl být odpovědným účastníkem obchodu, který činí informovaná rozhodnutí při nákupu zboží a služeb. Spotřebitelé mohou nakupovat po celé Evropě, což podporuje kvalitu hospodářské soutěže v rámci celé EU.

Evropská komise přijala 10 pravidel ochrany zájmů spotřebitele: [17]

1. Nakupujte, co chcete a kde chcete.

2. Pokud je zboží vadné, vrat'te ho.

3. Vysoká úroveň bezpečnosti potravin a spotřebního zboží.

4. Informujte se o tom, co jíte.

5. Smlouvy musejí být čestné vůči zákazníkům.

6. Spotřebitelé mohou někdy měnit svá rozhodnutí.

7. Možnost jednoduššího porovnání cen.

8. Spotřebitelé by neměli být klamáni.

9. Ochrana spotřebitele během dovolené.

10. Účinné urovnávání přeshraničních sporů.

V oblasti spotřebitelské politiky a ochrany spotřebitele si Evropská komise vymezila pro období 2007-2013 tyto základní cíle: [22, s. 5]

- Posílit postavení spotřebitelů vEU, předat kontrolu spotřebitelům v zájmu posílení hospodářské soutěže.

- Zvýšit blahobyt spotřebitelů v EU z hlediska ceny, výběru, kvality, různorodosti, dostupnosti a bezpečnosti. Blahobyt spotřebitele je středobodem dobře fungujících trhů.

\footnotetext{
${ }^{5}$ Upraveno dle Dokumentu Strategie spotrebitelské politiky EU 2007-2013.
} 
- Účinně chránit spotřebitele před závažnými riziky a hrozbami, se kterými si jakožto jednotlivci nemohou poradit. Vysoká úroveň ochrany proti těmto hrozbám je pro důvěru spotřebitele nezbytná.

Cílem Komise je tímto zpo̊sobem dosáhnout do roku 2013 propojenějšího a efektivnějšího vnitřního trhu, zejména pokud jde o jeho maloobchodní rozměr.

\section{Česká republika}

Na úrovni České republiky byla zpracovaná Koncepce spotřebitelské politiky na léta 20062010, na léta 2011 - 2014 jsou zpracovány Priority spotřebitelské politiky. Hlavní oblastí zájmů těchto koncepcí je ochrana zdraví a bezpečnosti, ochrana ekonomických zájmů, odškodnění, informovanosti a výchovy, sdružení k ochraně spotřebitelů, životní prostředí a sociální dopady spotřeby. Ochrana spotřebitele má své základní priority: [22]

- zvyšování znalostní úrovně v oblasti ochrany spotřebitelů, rozvoj pro-aktivních informačních a vzdělávacích aktivit ve prospěch spotřebitelů;

- bezpečnost výrobků a služeb;

- zvýšení efektivity regulace oblasti;

- podpora samoregulace, dialogu státních institucí se spotřebiteli a dialogu mezi podnikateli a spotřebiteli;

- zvýšení účinnosti tržního dozoru;

- podpora rozvoje mimosoudního řešení spotřebitelských sporů,

- podpora činnosti a rozvoje spotřebitelských organizací,

- podpora aktivit souvisejících s realizací udržitelného rozvoje spotřeby, napřr. cestou změny vzorců spotřeby.

Priorita zvyšování znalostní úrovně v oblasti ochrany spotřebitelů včetně mapování nových trendi̊ na trhu ovlivňujicích ekonomické a dalši aspekty rozhodování spotřebitelů by měla představovat aktivity, na kterých se bude ČR společně podílet s Evropskou komisí. Společné mezinárodní studie, jež by byly výstupem této spolupráce, by se měly zaměřovat např. na cenová srovnávání, indikaci spotřebitelských postojů a míry jejich spokojenosti, posílení bezpečnosti výrobků a služeb, ochranu spotřebitelů při využívání telekomunikačních služeb, dopravních služeb apod. Cílem priority zvýšení efektivity regulace $v$ oblasti ochrany spotřebiteli̊ je nutné zajistit, aby bylo důsledně a efektivně vymáháno právo prostřednictvím orgánů dozoru nad trhem. Nedílnou součástí je mezinárodní spolupráce s Evropskou komisí i s dozorovými orgány ostatních členských zemí EU. Při tvorbě legislativních opatření regulujících kroky v oblasti ochrany spotřebitelů je důležité přihlížet k principům Strategie udržitelného rozvoje ${ }^{6}$ v České republice, která byla přijata v roce 2004 a také Rámce programů udržitelné spotřeby a výroby, které byly schváleny Radou pro udržitelný rozvoj ${ }^{7}$ v roce 2005. Podpora uplatñování principu samoregulace, dialogu státních institucí se spotřebiteli a dialogu mezi spotřebiteli a podnikateli se zaměřuje na řadu oblastí, [11] jsou velmi důležité pro komplexní pohled na ochranu spotřebitelů. Za všechny můžeme jmenovat zejména podporu vzniku kodexů etického chování podnikatelských subjektů včetně vytváření nástrojů k zajištění praktické realizace těchto kodexů, prohlubování dialogu spotřebitelů se státními institucemi především ve formě vytváření podmínek pro účast spotřebitelů při projednávání záležitostí dotýkajících se spotřebitelů; možnost uplatnit připomínky v rámci legislativního procesu, zapojení do různých pracovních skupin ke konkrétním okruhům, např. vytváření norem, podporu a budování kapacit spotřebitelských organizací, reprezentaci zájmů

\footnotetext{
${ }^{6}$ Udržitelný rozvoj- rovnováha mezi základními oblastmi života - ekonomikou, sociálními aspekty a životním prostředím.

${ }^{7}$ Rada pro udržitelný rozvoj je stálý poradní, iniciační a koordinační orgán vlády ČR pro oblast udržitelného rozvoje a strategického řízení.
} 
spotřebitelů na evropských a mezinárodních fórech, zejména prohloubení účasti zástupců spotřebitelů $\mathrm{v}$ oblasti standardizace, prohlubování dialogu mezi zástupci spotřebitelů a podnikateli.

Účinnost tržního dozoru by měla být posílena principy samoregulace, dialogu státních institucí se spotřebiteli a dialogu mezi spotřebiteli a podnikateli. Oblastí zvýšení účinnosti tržního dozoru je celá řada. Jedná se především o bezpečnost výrobků, ochranu ekonomických zájmů spotřebitelů, ochranu ve finančních službách při cestovních, v ecommerce, vzdělávání osob vymáhajících dodržování práva a vytvoření uživatelsky přátelského vzájemně provázaného systému informací dozorových orgánů přístupných široké spotřebitelské veřejnosti. Za rychlý, levný a vhodný způsob vyřešení nároku spotřebitele je celosvětově považován institut mimosoudního řešení spotřebitelských sporů

Rozvoj pro-aktivních informačních a vzdělávacích aktivit ve prospěch spotřebitelů [11] by se měl zaměřit na podporu fungování a rozvoje aktivit Evropského spotřebitelského centra, podpora vzdělávání spotřebitelů, podpora aktivit zaměřených na zvyšování informovanosti spotřebitelů, podporu zavádění konkrétních programů udržitelné spotřeby, vydávání publikací, využívání internetu a medializace spotřebitelských práv.

Velký význam při ochraně spotřebitelů mají spotřebitelské organizace, které by měly poskytovat poradenskou činnost a informovat spotřebitele. Tyto organizace by měly být nezávislé na podnikatelské veřejnosti a pracovat v souladu se svým etickým kodexem.

\section{Koncepce společenského marketingu - vybrané pozitivní a negativní příklady z praxe}

V empirické části našeho článku se pokusíme představit vybrané výsledky dílčí vstupní analýzy, opřené o dostupné sekundární údaje (pozitivní a negativní př́klady, viz tabulka 3.1 a 3.2), které mohou ukázat na hlavní problémové oblasti. Vzhledem k tomu, že se domníváme, že společenský marketing by měl využívat standardních marketingových nástrojů při zpracovávání marketingové strategie, zvolili jsme tento přístup i my. Vzhledem $\mathrm{k}$ možnému rozsahu článku uvedeme jen některé př́klady týkající se prvku produkt a marketingová komunikace.

Prohřešky se velmi často řetězí a zmnožují a zasahují více složek marketingového mixu. Tedy samotný produkt je prohřeškem, současně jeho cena a s tím i související reklama a podobně. Mnohé z nich de facto ovlivňují celé marketingové instrumentárium. Obecně lze říci, že každý den nacházíme $\mathrm{v}$ televizi, $\mathrm{v}$ tisku, rozhlasu desítky prŕípadů hrubého zneužití jednotlivých nástrojů nebo celých skupin, a tím porušení společenské marketingové etiky.

\section{Produkt}

Filosofie společenského marketingu se zřetelem na potřeby spotřebitelů i společnosti by měla začínat již při výrobě a pokračovat na celé cestě ke spotřebiteli. Za pozitivum můžeme považovat, že již ve výrobě dochází ke standardizaci sortimentu, která může přinést zvýšení kvality zboží. Výrobce musí prokazovat od 1. 1. 1995 tzv. shodu před vstupem na trhy EU, což znamená, že jeho nabízený výrobek musí splňovat závazné předpisy a normy. V řadě zemí se vytváŕí legislativa k ochraně zájmů spotřebitelů, která zlepšuje jejich postavení na trhu a přispívá ke zkvalitnění uspokojování jejich potřeb. I samotný spotřebitel přispívá k posílení koncepce společenského marketingu. Téměř 3/4 Evropanů preferují značky 
nabízející ekologické a Fair Trade produkty.[8, s. 18-19] Podniky jsou motivovány k zapojení do koncepce společenského marketingu různými soutěžemi.

$\mathrm{Na}$ druhé straně nemůžeme být spokojeni z hlediska ochrany zájmů spotřebitelů, že se nesnižuje počet oznámení na nebezpečné výrobky, jako jsou hračky či elektrické spotřebiče nebo svítidla, které ohrožují zdraví zákazníků. Počet zachycených nebezpečných výrobků na trzích zemí EU má rostoucí tendenci. Státní dozorové orgány a spotřebitelské organizace na vnitřním trhu Evropské unie v roce 2008 zachytily 1866 nebezpečných nepotravinářských výrobků, což bylo o $16 \%$ více než v roce 2007. [12, s. 40] Některým výrobcům je jedno, že nabízejí zákazníkům náhražky (pochybné ingredience prodávané mnohdy se značkou, např. čokoládové figurky nebo sýry. [20, s. 61] V možnostech spotřebitele není zjistit, zda se jedná o náhražku.

V roce 2008 provedli inspektoři Státní zemědělské a potravinářské inspekce v ČR více než 73 tisíc cíleně zaměřených kontrol, přes 10 tisíc u výrobců potravin rostlinného původu a přes 63 tisíc v obchodní síti. V rámci těchto kontrol zjistili 5878 nevyhovujících vzorků potravin. [19, s. 42]. V České republice byly také při prodeji potravinářského zboží odhaleny kauzy s podvodným prodejem potravin (maso, sýry).

Tabulka 3.1 Pozitivní a negativní př́íklady na úrovni nabízeného produktu

\begin{tabular}{|c|c|}
\hline Pozitiva & Negativa \\
\hline $\begin{array}{c}\text { Standardizace sortimentu a sjednocení } \\
\text { technických předpisů a rovnocennosti } \\
\text { norem řady ISO 9000 ve státech EU. }\end{array}$ & $\begin{array}{c}\text { Vysoký počet upozornění } \\
\text { na nebezpečné výrobky v rámci EU }\end{array}$ \\
\hline $\begin{array}{c}\text { Prokázání shody a získání značky CE } \\
\text { (Conformité Européenne) }\end{array}$ & $\begin{array}{c}\text { Nárůst nebezpečných výrobků } \\
\text { na trhu EU }\end{array}$ \\
\hline $\begin{array}{c}\text { Ekologické značky, značky Fair Trade } \\
\text { Zxistence výrobků bez značky shody, } \\
\text { bez označení výrobce, } \\
\text { za jakost, Cena ČR za jakost, Cena Anežky } \\
\text { Žaludové), }\end{array}$ & $\begin{array}{c}\text { Nezájem některých výrobcú } \\
\text { na kvalitě nabízeného potravinář́ného zboží } \\
\text { (pochybné ingredience, náhražky apod. }\end{array}$ \\
\hline
\end{tabular}

Pramen: Vlastní zpracování

\section{Marketingová komunikace}

Cílem marketingové komunikace je oslovení zákazníka za účelem prodeje zboží i vyváření pozitivního image firmy na veřejnosti. Tato oblast marketingových aktivit firem vytváří prostor pro řadu pozitivních a prospěšných činností, které př́ispívají k lepší informovanosti spotřebitelů a zkvalitňují tak celý proces budování vztahů se zákazníky. I zde se ale setkáváme s klamavou reklamou či nepoctivostí, které sledují pouze zisk firmy a s koncepcí společenského marketingu nemají nic společného.

Existuje legislativa týkající se etiky v marketingové komunikaci (ČR např. Zákon č. 40/1995 Sb., o regulaci reklamy, Obchodní zákoník, č. 513/1991 Sb. upravující nekalou soutěž ...). Základní „normou“ pro autoregulaci je etický Kodex reklamy Rady pro reklamu a případně etické kodexy dalších sdružení. Mnohé firmy se snaží lépe informovat své zákazníky o zboží. Informace o netestování zboží na zviŕratech je dnes považována za konkurenční výhodu. Zajištování zpětné vazby od zákazníka o úrovni uspokojování jeho potřeb by mělo být nezbytnou součástí řízení vztahů se zákazníky a budování koncepce společenského marketingu. Také sociální sítě mohou přispět pro zjišt’ování názorů zákazníků na úroveň uspokojování jejich potřeb. 
Tabulka 3.2 Pozitivní a negativní příklady na úrovni marketingové komunikace

\begin{tabular}{|c|c|}
\hline Pozitiva & Negativa \\
\hline $\begin{array}{c}\text { Legislativa týkající se etiky } \\
\text { v marketingové komunikaci }\end{array}$ & $\begin{array}{c}\text { Existence klamavé reklamy } \\
\text { a propagace a nátlakové metody prodeje }\end{array}$ \\
\hline $\begin{array}{c}\text { Existence etických kodexů - autoregulace } \\
\text { ojednoznačné a nesrozumitelné informace } \\
\text { o prodeji }\end{array}$ & $\begin{array}{c}\text { Nesrozumitelné internetové portály } \\
\text { o výrobcích }\end{array}$ \\
\hline $\begin{array}{c}\text { Zjiššrování zpětné vazby } \\
\text { od spotřebitelů, dotazníková šetření, } \\
\text { ankety, sociální sítě }\end{array}$ & $\begin{array}{c}\text { Nedostatečná informovanost spotřebitelů } \\
\text { o výsledcích kontrol } \\
\text { v ČR }\end{array}$ \\
\hline
\end{tabular}

Pramen: vlastní zpracování

Negativní příklady v oblasti marketingové komunikace se týkají především klamavé reklamy. Firmy poskytují svým zákazníkům zkreslené informace o výrobcích. Vyskytují se informace, které jsou nejednoznačné a nesrozumitelné o prodeji, které uvádějí spotřebitele $\mathrm{v}$ omyl. Slibují různé výhry a často zavazují spotřebitele k dalším nákupům. [15, s. 4]. Některé nesrozumitelné internetové portály dezinformují spotřebitelé a nutí je k placení poplatků za informace o nabízených službách, které si de facto nevyžádali. [25] Velmi neetické jsou také různé nátlakové prodejní metody, které využívají fïmy při organizování různých párty či výletů, jejichž součástí je i nabídka různého zboží. Často na tyto aktivity doplácejí starší věkové skupiny zákazníků. Svoji negativní roli zde sehrává i stát, když neposkytuje dostatečné informace o výsledcích kontrol dozorových orgánů.

\section{Závěr}

Přijetí koncepce společenského marketingu a růst etického chování podniků na úrovni výroby i služeb by přispělo významně k dodržování pravidel ochrany spotřebitelů. Zveřejňování výsledků z kontrol dozorových orgánů by nejen zvýšilo informovanost spotřebitelů, ale také pomohlo při jeho lepším a plnohodnotnějším rozhodování. Samozřejmě na principu svobodné volby. Pro podnikatele by se vyšší informovanost, at' už v pozitivním smyslu či negativním smyslu stala součástí konkurenčního boje. V celkové koncepci tvorby strategického marketingového řízení je nutno počítat na prvním místě s lidským faktorem, který by měl být nositelem a inspirátorem společenského marketingu i marketingu v organizaci vůbec.

\section{Literatura:}

[1] Aktuální trendy v maloobchodě. Moderní obchod, 2010, č. 7-8, s. 18-19. ISSN 12104094.

[2] DUBCOVÁ, G. Význam etického kodexu pre podnikatelskú sféru. In Sborník z mezinárodní vědecké konference Nová teorie ekonomiky a managementu organizací. 1. díl. Praha: VŠE, 2006. ISBN 80-245-1091-X.

[3] DYTRT, Z. A KOL. Etika v podnikatelském prostředí. Praha: Grada Publishing, 2006. ISBN 80-247-1589-9.

[4] FIALA, B. Podniková etika. Olomouc: Univerzita Palackého, 2005. ISBN 80-2441241-1.

[5] HOROVÁ, O. Ochrana spotřebitele v podmínkách EU. In Sborník z mezinárodní védecké konference Nová teorie ekonomiky a managementu organizací. 1. díl. Praha: FP, VŠE, 2006. ISBN 80-245-1091-X.

[6] Koncepce spotřebitelské politiky na léta 2006 -2010. Praha: MPO, 2006.

[7] Kontroly přitvrdily. Moderní obchod, 2009, č. 6, s. 40. ISSN 1210-4094.

[8] KOTlER, P., WONG, V., SAUNDERS, J., ARMSTRONG, G. Moderní marketing. Praha: Grada Publishing, 2007. ISBN 978- 80-247- 1545-2. 
[9] Krize podporuje „chytrou spotřebu“. Moderní obchod, 2009, č. 5, s. 18. ISSN 12104094.

[10] KRYMLÁKOVÁ H. A KOL. Etika a odpovědnost organizace. Ostrava: VŠB-TU Ostrava, 2009. ISBN 978-80-248-2092-7.

[11] MARHOUNOVÁ, M. Etické aspekty marketingového rozhodování. In Sborník z mezinárodní védecké konference Marketing, obchod a právo. Ostrava: EK f VŠB-TU Ostrava, 1997. s. 253- 257. ISBN 80-7078-455-5.

[12] MATUSÍKOVÁ, L. Percepce spotřebitelských práv ve světle obchodní strategie. Karviná: SU OPF, 2008. ISBN 978-80-7248-503-1.

[13] Nekalé obchodní praktiky. Test, 2010, č. 5, s. 4. ISSN 1210-731X.

[14] Novela zákona o potravinách. Moderní obchod, 2008, č. 6, s. 53. ISSN 1210-4094.

[15] Ochrana spotřebitele v Evropské unii. Brusel: Evropská komise, 2005. ISBN 92-7900200-7.

[16] Pečlivě hlídané kategorie. Moderní obchod, 2010, č. 6, s. 26. ISSN 1210-4094.

[17] Slabá místa na trhu s potravinami. Moderní obchod, 2009, č. 5, s. 42. ISSN 1210-4094.

[18] Spotřebitelův guláš a klamavé praktiky. Moderní obchod, 2008, č. 6, s. 61. ISSN 1210-4094.

[19] STARZYCZNÁ, H., PELLEŠOVÁ, P. Teoretická východiska řízení vztahů se zákazníky - Customer Relationship Management. (z výzkumné zprávy Grantového projektu reg. č. 402/05/0140). 2/2005. In Acta academica karviniensia. Karviná: SU OPF, 2005. s. 148-156. ISSN 1212-415X.

[20] Strategie spotřebitelské politiky EU 2007-2013. Brusel: Komise Evropských společenství, 2007.

[21] Tesco sází na ekologii. Moderní obchod, 2010, č. 9, s. 42. ISSN 1210-4094.

[22] VAŠTÍKOVÁ, M. Marketing služeb - moderně a efektivně. Praha: Grada Publishing, 2008. ISBN 978-80-247-2721-9.

[23] Vyhlášením výsledků kontroly nekončí. Moderní obchod, 2010, č. 7-8, s. 16-17. ISSN 1210-4094.

[24] ZAMAZALOVÁ, M. Marketing obchodní firmy. 1 vyd. Praha: Grada Publishing, 2009. ISBN 978-80-247-2049-4.

\section{Internetové odkazy}

[1] Další podvodné faktury ze Slovenska. [on-line] [cit. 2010-27-9] Dostupné $\mathrm{z}:<\mathrm{http}: / / \mathrm{www}$. spotrebitele.info/informatika_telekomunikace/clanek.shtml? $\mathrm{x}=2355015>$

[2] EU má půl miliardy. [on-line] [cit.2010-16-9]. Dostupné z: $<$ http://aktualne.centrum.cz/zahranici/evropska unie/clanek.phtml?id=674410>.

[3] KNOBLOCHOVÁ, V. Vývoj ochrany spotřebitelů v EU. [on-line] [cit. 2010-16-9]. Dostupné z: <http://www.mpo.cz/dokument7587.html>.

[4] Spotřebitelé. Ochrana vašich práv. Konkrétní výsledky.[on-line] [cit. 2010-16-9]. Dostupné z: <http://europa.eu/pol/cons/index_cs.htm>.

\section{Klasifikace JEL: M31}

Mgr. Pavla Sýkorová, doc. Ing. Halina Starzyczná, Ph.D., doc. Ing. Emanuel Šustek, CSc.

Slezská univerzita v Opavě

Obchodně-podnikatelská fakulta v Karviné

Katedra marketingu

Univerzitní nám. 1934/3

73340 Karviná

sykorova@opf.slu.cz, starzyczna@opf.slu.cz, sustek@opf.slu.cz 